\title{
Post-Communist Systemic Change: Lessons for East Asia
}

\author{
László Csaba
}

With the North Korean waves of armament race in 2017-19, noted by the diplomacy of the Trump Administration, de-nuclearization has become a top priority for the Korean peninsula. In the meantime potentials for economic reforms in North Korea, perhaps even to the point of systemic change, are still open issues, as the need to feed people and improve the dismal economic performance remains high on the agenda. What lessons might be learned from the systemic change of Central and Eastern Europe for the context of East Asia? Implications based on International Relation (IR) theory are suggested.

Keywords North Korea, de-nuclearization, participatory change, developmental state, shock therapy

\section{Introduction}

With the emergence of North Korean nuclear and ballistic capabilities and the enhanced focus of the Trump presidency on dealing with North Korea (New York Times 2019) one important issue among the many ensuing puzzles has remained that of the North Korean economy. How can such a weak, partly over-centralized, and partly disorganized economy, as neatly described by Kim (2017), afford the nuke? And what will be the result from the ever increasing centralization of the North Korean leadership on the economy? And if change towards decentralization is to occur any time in the future, what are the prospects and limits for such change?

This article conducts a mental experiment. Without discussing the most important political side-conditions, which would require a separate monograph

This lecture was delivered at a conference organized by the Institute of Korean Studies (IKS) and the Institute for Peace and Unification Studies (IPUS) entitled, "Conflict and Integration as Conditions and Processes in Transitioning Societies of Eastern Europe and East Asia," and held at the Freie Universität Berlin on November 9, 2017. 
of their own, or perhaps reliance on collective wisdom, we presume that largescale economic change may be forthcoming. Under this hypothetical scenario we ask the very practical issue, if and what lessons are to be learned from the Central and Eastern European experiment, whose thirtieth anniversary is at the time of writing. We are fully aware of the major limitations of transferring regionspecific experiences from one socio-political context to the other. Still, it might be expedient to have some ideational preparedness should fundamental change in North Korea occur any time in the future. As a participant observer, the author is painfully aware of the burden of ignorance East Europeans carried with them during the economic transformations of the 1970s and 80s, given that their contemporary professional knowledge was limited to improving the Communist economy, which was considered at the time to be ever-lasting.

\section{Consequences of Lack of Theory and Experience}

Large-scale political, institutional, and economic change in Central and Eastern Europe took by surprise not only the population at large but also the majority of analysts and, in particular, economists. Most of us considered dealing with the 'real thing, namely how to introduce a true market economy, irrelevant as excluded by political constraints. Thus when the Soviet Union collapsed, in hindsight by historic necessity rather than as an outcome of policy blunders, economists were not only woefully ignorant about what to do, but even less knowledgeable about how to manage the change in a socially acceptable fashion.

Ever since that period a burgeoning and controversial analytical literature has emerged covering both country experiences and functional themes (Turley and Hare 2013; Kolodko 2014). Despite the richness of the source material and the ongoing production of output in academic journals regarding Central and Eastern European transition, some of the fundamental issues remain open to further discussion.

Firstly, large-scale systemic transformation covering all subfields of systemic totality, including politics, economics and social structure, is not a unique phenomenon, but something that has been experienced and studied in various periods in history and various country groups (Kollmorgen et al. 2019). These broad overviews highlight the historic uniqueness of post-communist change in all three subsystems. The ex post analyses underscore a factor poorly understood by contemporaries, namely that the reversal of the legacies of Communist system is much more difficult, time consuming and also costly in social and economic terms, than any of the post-war reconstructions or post-crisis financial stabilizations. Knowledge of both were available at the onset of transitions, however these insights were partial, fragmentary and not integrated in a single analytical framework. Attempts to apply the contemporary International 
Monetary Fund (IMF) wisdom, the so-called Washington Consensus have yielded limited results, not the least owing to the cognitive insights (Winiecki 1993) and also to the partial applications of policies (Marangos 2007) exacerbated by features of state capture and marked limitations on state capacity, experienced primarily but not exclusively in the post-Soviet and post-Yugoslav spaces.

Let us note that at the time of launching transformation the general expectation was no more and no less than a replica of the post-war Wirtschaftswunder, the fast reconstruction and steep recovery of living standards not only to the previously achieved levels, but way beyond them, leading to sustaining welfare and its trickle down to all major segments of society, including the weakest. This is likely to be the case in North Korea, in perhaps an even more pronounced manner. It is true that rebuilding of war-torn economies proved fast both following World War I-as indicated by the 'roaring twenties' - and even more so in the decades after World War II. In the latter, expansion of the various forms of universal welfare state has contributed to the expansion of mass consumption and also to the steady improvement of all human development indicators.

However the 'golden years' of 1950-1973 were built on a series of unique non-replicable factors, well covered by the literature on economic history (Berend 2006). Namely the combination of favorable global conditions, the regulated international financial system coupled with very incremental trade liberalization, de-militarization, policies of full employment and the favorable, Keynesian effect of the growth of mass consumption on both output and employment together constituted a unique constellation. What sounds by today's standards to be a platitude for the economic historian was in fact a cold shower for East European societies expecting in vain the simple repetition of the postwar improvement. Moreover, nowhere, not even in the homeland of the economic miracle, Germany, could one observe the carbon copy of postwar recovery in the 1990-2015 period, especially if we focus on the new provinces of the former East German communist state. In the East German provinces real convergence has come by and large to a halt in 1996-97, and the outflow of population since then far exceeded the flight of people in 1949-61 period, when the one party dictatorship seemed to be a transitory arrangement with re-unification explicitly figured in the East German constitution and the country's anthem alike. Unemployment rate is typically twice as big in the new as in the old Laendern, and very few top players are found either among research universities or in the Bundesliga.

\section{First Order Explanations: Policy Blunders}

If we are to explain the lack of progress and lack of catching up along the lines postulated by neoclassical growth theory and neo-functionalist integration theories, the first and most popular set of explanations are references to policy blunders. For simplicity's sake our rod of measure is not a set of new speculations 
about the 'new normal' of the post-crisis period, but we stick to the practices of the 1992-2007 period of Great Moderation, when an eclectic set of policies ensured high growth and reasonable financial equilibrium - both external and internal - in the Organisation for Economic Co-operation and Development (OECD) area. It should be noted that this period seemed particularly favorable for countries at lower level of development assisting with their catching up to international market standards. External markets were opening up and financial markets were accessible. Financial deepening allowed for countries to tap savings of others, and low or sometimes even negative real rates of interest, stemming from the Greenspan policies of ultra-lax monetary policies and non-intervention (even de-regulation) in financial markets together favored the financially less solid players.

In the post-communist region the slap in the face was threefold. First, nobody expected - although it could have been in some ways - that the collapse of Communism will trigger a deep recession first before recovery may start (Csaba 1993; Kornai 1993; Winiecki 2002). This had to do with features inherent in postcommunist change, namely that 'no gain without pain' implied that good polices were bound to trigger bad results first. The good policies included the closure of inefficient firms, opening up markets, introducing market clearing prices and bankruptcy procedures, introducing proper accounting both at the corporate and national levels, balancing the budget, and making the central bank independent. Re-orienting foreign trade from administratively over-protected eastern, Council for Mutual Economic Assistance (CMEA) markets to the global economy was bound to be painful and contractionary, as known from developing country experiences with trade liberalization. This insight should be factored into any project of re-construct in North Korea.

The second slap in the face came from the fact, that recovery of output and living standards (not however of employment) started late - as late as 4-5 years in central Europe and the Baltics and more than a decade after the onset of transition in the rest of the countries. Pre-crisis levels were attained in 1999 in Central Europe and the Baltics and as late as 2004 in the rest with some exceptions (Moldova, Kosovo, Macedonia, Georgia, and Armenia) faring even worse. Fifteen years is a long time, especially if one compares these timeframes to the context of post-World War I and post-World War II experiences of a similar 4-5 years delay.

In the following this article will attempt to sum up the most important explanations for why similar post-war economic miracles have yet to materialize despite intensive interchange with western advisors, academics and despite institutional integration in both the global, World Trade Organization (WTO), International Monetary Fund (IMF), and regional, European Union (EU), framework.

The standard policy package, as currently defined, is clearly the SLIP agenda. The English pun is a shorthand for the package of stabilization, liberalization, 
institution building and privatization (SLIP). No serious analyst questions the validity of this agenda any longer, not even the sequence as figured in the order of letters (if we think normatively), although this has not always been the case in the contemporary literature.

In terms of stabilization we have to refer to the notoriously weak position of governments. This is the fundamental explanation for the delays in stabilization in all cases except for Croatia, Czecho-Slovakia, Slovenia and Estonia. Delayed stabilization is shown to be the immediate case for slow and delayed recovery of output (Roaf et al. 2014).

In terms of liberalization the case is more complex. Empirical and comparative studies (Winters 1995) have shown, that as in any pluralist society, interest groups are diverse and adopt different policy agendas. Therefore trade liberalization, and more over the broader factor market liberalization and creation of contestable markets is much more burdensome, in both theory and policy terms, than the textbook view would have it. In the transition countries, two types of experience prevailed. In those acceding to the EU unilateral liberalization monitored by an international agency was implemented, for the benefit of the local consumers, i.e of the vast majority. By contrast, in the non-EU countries and most particularly in the New Independent States (NIS) and on the Balkans, old-fashioned protectionism based on pork-barrel policies survived. As has been argued before (Csaba 2007), trade and investment liberalization was a crucial factor for explaining the success of transformation both in terms of growth and in terms of integration in the global value chains.

Institution building has also proven to be more complex than originally conceived. This is due, not in the least, to the inherent limitations of transplanting well-functioning regulations even within a single transnational regulatory field (Bruszt and McDermott 2014). Transplants do not flourish in most of the cases. Thus even if the EU mandated and controlled the adoption of a series of macroregulatory arrangements, implementation on the ground remained perfunctory, formal and often openly negligent.

Finally, privatization was bound to be contentious, as is the case in any economy and society. Changing the balance of power, changing the beneficiaries, changing the dependent and independent variables is a prime issue of political competition and power structure in any country. Therefore, while it tended to be seen as axiomatic, we should in reality not be surprised to see the process reversed in the current decade (Szanyi 2016; Voszka 2018). Privatization tended to be even more controversial than in western societies, because it covered 50 to 80 percent of national wealth in a short period of 4-5 years, as opposed to 10-12 years and 3-4 percent of national wealth in the United Kingdom under the Thatcher years. Furthermore in central Europe the process has created a predominantly foreign ownership in many key sectors, as banking and energy and transport, where strategic decisions are often made abroad. This creates a 
potential conflict of interest situation for activist local governments.

In the alternative path taken by the NIS governmental, political leveraging has become pre-eminent (Kosals 2007; Yakovlev 2006). This implied that many business tycoons often play a formative role in power plays, and in converse, the government is frequently the real arbitrator in economic beauty contests. Creating or preserving monopoly positions, as e.g. for Sberbank and the infamous Aeroflot count just as tip of the iceberg (in both cases retaining old monopoly positions from the Soviet period well into the current decade, in exchange for subservient attitudes as policy instruments for the Russian state domestically and abroad alike). Yet another important policy lesson for East Asia: transition packages, such as SLIP package, may and do help, but improvement is by no means automatic or unconditional, state activity in sustaining competition is a key factor.

\section{Second Order Explanations: Cognitive Constraints}

It would be ahistoric to assess 1989-95 projects and visions on the ground of current knowledge of what is often termed the "new normal" (Blanchard et al. 2016). Transition planning-and implementation — can only be judged against contemporary standards, also in terms of academic knowledge.

We have extensive volumes by now (Wagener 1998; Kaase et al. 2002) documenting that economic knowledge in the East European countries tended to be highly specific, tailored to the needs of the command economy. Reform thinking had largely been constrained by the implicit and explicit assumption of an ever-lasting Soviet Union with the ensuring dominant role of the Communist Party and Marxian orthodoxy. Nobody, including the author of this article, envisioned that the Soviets would leave without a single shot of a rifle, and communist rulers would give way via negotiated revolutions, in a predominantly peaceful and top-down, organized manner, handing over the commanding highs to their adversaries.

This state explains why most of the local output, even the bulk of the radical reformist thinking, revolved around improving, rather than replacing, the basic structures of a command economy. Adding limited elements of market to the planned economy, allowing for mathematically constructed pricing, or even market clearing prices in some sector, liberalizing the small business sector was the most to be attained. Even if and when measures transcending the traditional boundaries, such as the establishment of a two tier banking system in Hungary in 1987 with independent commercial banks running on the profit principle or introduction of the stock exchange in 1988, have all been made under tight Party supervision. As it is common knowledge by now, largely owing to the Chinese experience, none of these measures lead automatically to the weakening of communist control (Du 2018).

Therefore an interesting dualism has emerged. Some people, mostly representing established academic and political elite, banked on radicalizing their 
existing arrangement and knowledge and were involved in building mainly upon the status quo, both in political and economic terms. They were the 'gradualists' mostly of social democratic leanings or Christian-Socialist references. By contrast, those who wanted a radical discontinuation of the past, primarily those of libertarian or neoconservative persuasions, tended to bank on importing first-class, first-hand knowledge, primarily from top U.S. universities and the Washington Twins. They became the "shock therapists" who favored to conduct 'as many good policies as possible at the same instant' as the common formulation went.

It is quite correct to remind the later readers (Haiduk 2016, 250) that there is a substantial distance between even the best of economic theories, which are inherently abstract, and the concrete policy settings of any country, but particularly any post-Communist nation as of 1990 or 1995. By the same token, as the Belorussian economist Kiryl Haiduk (2016) elaborates lucidly, much of the debate regarding transition in terms of substance and even more in terms of implementation had to be home grown rather than simply adopted.

What is remarkable about this insight is that it explains a large degree of otherwise quite implausible naiveté, utopianism and obvious day-dreaming, that is extreme forms of social constructivism on the side of those, who otherwise relied on popularized and simplified concepts attributed to-rather than properly taken over from-Hayek and Friedman. Radical reformers, which abounded in each country, and considered themselves absolutely as 'practical men', as Keynes would call them mockingly, like Václáv Klaus, the later Czech President, or Anatoly Chubais, still running the Russian electricity monopoly.

It would be cheap to ridicule many of the contemporary ideas about fast and painless privatization, instant recovery, and rapid, seamless integration into the European and global institutional structures. What we find important is to remind the reader that the western profession also had little useful knowledge to offer in the first fifteen years of transition. All in all, it may be legitimate to claim that lack of human capital may count, even with the benefit of hindsight, among the most relevant and binding constraints on successful transition. Given three generations of narrow family rule in North Korea, this factor may be even more compelling.

This lack of human capital had to do with several, interrelated factors. Number one is the rule of neoclassical orthodoxy at the top universities, which had become uncontested by the early 1990s. Mainstream economics is known to disregard history and institutions: two factors which play an important role in policy-making. By contrast, in contemporary macroeconomics the Lucas school prevailed where modelling is everything, coherence rules, mathematics is the theory, and, conversely, real world issues are ranked second or deemed completely irrelevant, as one scholars an extensive overview of the field describes (de Vroey 2016, 143-48). 
Second, adopting the mainstream view of overspecializing, compartmentalizing economic analyses translated into an overall disapproving of holistic approaches in particular. For this very reason, most if not all issues of transition tended to be treated separately, largely in isolation from one another. We had relatively insightful studies in regards to arresting inflation, balancing the budget, or privatization in terms of industrial organization. But that was a purely through a technocratic approach (Bornstein 1992), which excluded the discussion of the most contested issues of redistribution and power, laying at the heart of the contextual interpretation. Little wonder, in real world situations political constraints acted as a feedback loop, constraining the imagination and also the room for action for those designing the new economic system. With the revival of statism also in the West, East Asia is likely to experience the same backlash, the weaker the memory of private ownership is (as in North Korea), the sooner and more extensively such a backlash can be expected.

\section{Third Order Explanations: Path Dependency and Path Creation}

The farther we get from transition as a subject of immediate policy interest, and the more we adopt the long view and the more philosophical the explanation for the lack of success in most cases and the limited success in the fewer cases is bound to become. Interestingly, both in the policy and theory, and similarly both in the economic and historical literature, two opposing narratives emerged. One is the 'policy is everything' view, and its alternative is the 'institutions are everything' discourse.

The first narrative is cultivated by policy entrepreneurs, by those who have been involved in the decision-making process and also by those who work in international financial institutions, both governmental and private. Additionally such analysts as those trained in neoclassical tradition and following mainstream views in theory tend to associate themselves with this line of thought.

It would be hard to disagree with this position, insofar as we adopt a pragmatist view. In all countries, from Japan to Italy, policy-making has played a formative role in shaping outcomes. Likewise in highly successful cases, from Singapore to Switzerland, various forms of governmental action-including restraint or lack of corruption-have been formative in bringing about the outcomes. In fact, no theorist has ever seriously advocated for proverbial handsoff policies. When in government, economic liberals like Edward Lazear, Martin Feldstein or Gregory Mankiw, not to speak of the economic team of Donald Trump, have never suggested that their respective government should stay idle. Indeed, de-regulation and regulation as well as market protection and market opening policies are all activist forms of governmental presence in the allegedly self-regulating economy.

As a consequence, these policies, based on value judgements and ideologies, externally set objectives rather than mere survival policies, have been capable of 
moving some countries out of their historically determined levels of development and modus operandi in broad terms. South Korea is a case in point and, additionally, so are Israel and Hong Kong. From among the transition economies, although Estonia used to be the periphery of the Russian and Soviet Empires, currently Estonia is registered as US\$ 17, 574 (purchasing power parity in 2011) in per capita gross domestic products (GDP) at market prices according to the World Bank (2018). In contrast, Russia was only US\$ 8, 748, broadly the half in the same metric. This is what we call in economic theory and history path creation: moving out of what seems to have been predetermined by history, geography, and fate.

By contrast, in most of the cases regarding less successful countries, which predominate both globally and among the transition countries, a reverse reasoning may be due. Namely that history matters and geography matters. If one is to evaluate the lackluster performance of the central Asian and Caucasian countries, it would be hard to deny the important role of adverse geographical location. Being land-locked and situated at great distances from the major trading routes certainly influences what, even under the best of circumstances, any policy and policy-maker may attain. Georgia, for example, has embarked on ambitious reforms since the 2000s. However, owing to a military conflict with Russia in 2008 and the ongoing subversion of formal state structures by informal structures and various discontent groups, these measures could yield only very limited results.

But it is not only and not even primarily about geographical location. Technically speaking Singapore is in the middle of nowhere, while Sub-Saharan Africa enjoys long and warm seashores, which British and Dutch analysts tend to associate with prosperity and thriving finances. Economic location thus, it seems, is not primarily a geographic category.

Therefore when we talk about path dependence, we may rather think of traditions and other informal institutions which evolve in the long run and tend to change only very slowly over time. Many observers have noted that membership in the Hanseatic League may have contributed customs, laws and traditions that helped the Baltics over mainland Russia. Likewise centuries old democratic traditions in Poland have counter-acted centralizing tendencies both under Communism and in the post-2015 period of the illiberal turn. The 19$20^{\text {th }}$ century tradition of running a bank-based financial system could not be modified by the most radical projects of capital market development in any of the transition countries, perhaps owing to the long term path dependence.

Historians, ever since Frenand Braudel $(1969,1980)$, tend to stress that path dependence and path creation always co-exist, as such the real question is their actual mix. Economists, especially in the tradition of Douglass North (2005), but also following the narrative of Acemoglu and Robinson (2012) tend to place more emphasis on the long term influence of inherited institutions, colonial past and 
the heritage left by the Spanish versus the British core states.

Given that philosophical differences cannot be settled via recourse to a limited number of cases, with the inevitable coincidences in each, we may only observe, that transition theory has re-invented and re-produced those broader disagreements, which reign in both global economics and in global historiography. What we may add as a participant observer is that individual cases may and should not be assessed with reference to theories that apply to two or three levels higher in terms of abstraction than any concrete country case may illustrate. The experience of the split countries or areas which used to constitute a single unity, as former parts of the Ottoman Empire from Iraq to Israel may warn against too fast over-generalizations. Still, it would be hard to deny that 'history matters' if one thinks of any of the concrete cases. In Germany, for example, the horrific experience with Nazism did prompt a fundamental rethinking and reorientation in the western part, as an item of the historic turn taken by Konrad Adenauer. Still, with the east of the country left out of these processes the new Laendern continue to be different even three decades after re-unification, despite cultural, political and economic integration and a change of a generation. Three generations missed out in Vergangenheitsbewaeltigung, or facing the past in sincere and critical terms, which has been formative of the new post-war West German identity.

\section{Some lessons for East Asia and Korea}

First, re-unifying split countries and formerly single regions is much taller an order than the theory of economic integration would have it. Not only do we have few cases of real state convergence materializing in the present-day global community, but we also see sustained differences in what appears to be unitary states with relatively longish existences. In the case of Spain (Costa-i-Font 2014), regional differences have survived various periods of formal centralization, and subnational autonomy and identity shows no sign of subsiding. To a smaller degree the October 2017 referenda on more autonomy for Lombardy and Veneto expressed similar trends in Italy. The split of the Belgian state is a process which has been observable for two decades and the talk of the "Disunited Kingdom" is more than just another example of English humor. As mentioned above, differences in Germany are also observable after three decades of serious and expensive efforts. In Korea this will take even longer, given the extreme backwardness of the North in political and economic terms alike.

Second, the heritage of Communism is perhaps not only under-estimated by official statistics but also by the formal re-calculation of western experts, who rely singularly on quantitative indicators. The destruction of the social capital and social intangibles in society, extinction of the commercial spirit but also of classical 
moral foundations and the spread of disillusionment and cynicism are highly unfavorable conditions for a free, open society and a robust economy built upon such bases. The disregard for quality, environment, human conditions and the "development as freedom" (Sen 1999) constitutes an extremely difficult heritage for any new government.

Third, the longer the communist period lasted and the more it could rely on communitarian spirit and, in turn, the more difficult it will be to inspire the spirit of entrepreneurship, the feeling of individual responsibility, and the bigger the demand for enduring large state redistribution systems is going to be. This is by no means confined to welfare issues, as making individual(istic) decisions always runs a certain risk. While the American society is known to be risk-friendly, most Asian societies are not quite fully so.

Fourth, contrary to the preaching of some academics, there is no cookbook to go by. Each case is different, and as indicated in the introduction, even in Central European countries, with relatively long historic memories and shorter discontinuity from their historic developmental and cultural paths, basically 'everything' needed to be re-invented. Western academia has limited if any directly applicable insights for cases relatable to a potentially re-unified NorthSouth Korea would constitute. Post-communism leaves a demonstrably worse legacy against the recreation of a vibrant economy than post-war reconstruction had faced, and this is not due primarily to the Marshall Plan as usually invoked in response. In reality the EU has poured much more money than the Marshall Plan into countries like Greece, Portugal or Bulgaria without triggering the same outcome.

Fifth, context-specific knowledge is simply irreplaceable and so is tacit knowledge. In the case of North Korea one fears that so few individuals may be versed with this type of tacit knowledge that the feeling of being over-runparticularly strong among East Germans, the Scots, southern Italians, Catalans and Basques-may develop into a serious problem. Given that the Kohl Administration did go out of its way to sweeten the consequences of the superfast and militaristic, top-down, de facto and de iure take-over of an independent state with developing independent identity, and, yet, basically failed in the psychological sense.

Sixth, bringing about social consensus entirely bled out the need for things to become worse before they may-but not necessarily must-become better, is going to be even more of a gargantuan task, than it had been for the first kamikaze governments in Central and Eastern Europe. Governing coalitions that have managed transition in the first decade invariably disintegrated, should they have come from left or right.

Seventh, the international dimension is also extremely relevant. As discussed above and in the literature cited therein for Eastern European countries one of the fundamental challenges had been the change in their international 
embeddedness. Politically speaking they had been subjugated to the Soviet Union and Belgrade respectively, while economically they had been integrated into a protected and administratively managed environment, Council for Mutual Economic Assistance (CMEA) and the Yugoslav market. In both cases the protection offered sizable benefits in the short- and medium-term run allowing for the sustaining of obviously non-competitive and value-subtracting activities. The price for that was to be paid in the long-run, in terms of quality and competitiveness alike.

By contrast, North Korea is not part of an imperial economic and political structure, thus situations provoking more costly and economically difficult challenges are unlikely to emerge. Likewise as East Asian countries do not form any regional integration grouping that could be meaningfully compared to the European Union with its complex structures, largely closed economy, and single currency. Therefore managing transition is likely to be much easier from the structural and institutional points of view.

Eight, state capacity seems to be a crucial component in explaining transition outcomes in both the short and long run. The stronger the state is and the better the quality of governance (as against the predatory states in the New Independent States (NIS) is, then the smoother and shorter the path to prosperity is. Given that the South Korean state counts among the models of successful modernization and sustaining growth-even having come quite close to the former imperial Japan in terms of per capita GDP-this presents grounds for hope for a less thorny path to recovery than that of Eastern and Central European countries. According to World Bank (2018) South Korea stood at US\$ 34, 986 PPP per capita in comparison to Japan at US\$38, 240 at 2011 constant prices.

True, the developmental state has undergone fundamental changes in the past decade (Williams 2014), thus any idea to replicate the South Korean experience may be out of touch with contemporary realities. However the experience and the ensuing tacit knowledge and institutional capacity is there. Contrary to the German experience, global strategic considerations do not push for a blitz solution once the Communist régime is overcome. This allows for a much more patient and considerate management of societal and sociopsychological issues than was possible for the case in Germany. Opting for participatory solutions, rather than replicating the state-managed model of South Korean developmental state which has been described and popularized by Chun (2018), is the promising way ahead.

Ninth, a special challenge which is likely to predetermine much of the economics and politics of the future of North Korea including the specificities of transition is the nuclear issue. First and foremost the nuke may cherish illusions of stability and invincibility to the Communist Regime (see Wang 2008 for discussion). Second, as seen in Russia, Ukraine and Belarus, even if transition were to be peaceful, the massive development of the oversize military industry 
and the decades-long militarization of the North Korean economy and society is likely to create structural inertia, in which the move from one disequilibrium to the another is likely to be replicated.

The widespread presence of the irregular economy, shuttle trade, and corruption, neatly documented in Kim (2017) should not be seen as forward bastion of market relations. On the contrary, rule evasion, disrespect for privacy and property, degeneration of state capacity may all be warning signs and foreplays for lasting stagnation after stabilization.

Tenth, it would be wrong to paint an entirely bleak picture on the prospects of a potential North Korean transition to market and democracy. If lessons of Central Europe are indicative of anything many of the seemingly binding constraints might be alleviated. For instance integration to a robust regional neighbor and the global economy (including China), may help. Human capital, the most pressing bottleneck in managing change, may be improved by training and allowing for the importation of specialists from all around the globe, in management, schooling, finance and a variety of other disciplines.

\section{Peace-building and Social Acceptance: Keys to Sustainability}

As illustrated by our fragmentary and somewhat overly broad presentation of selected novel insights, the study of transition is not a narrowly confined subject in east European area studies, which may have some value for its socioanthropological peculiarity. In this article, we have tried to illustrate how socioeconomic insights matter for peace-building and how lessons may matter for an eventual re-unification of the Korean Peninsula.

Re-designing macro-economic and social systems is an open ended process, not confined to customary issues of the political economy of policy reform, as management of external debt or bringing about a workable and efficient tax system. As important as all these may be in their own right, these issues even as a collective whole may not meet the challenges posed by the ever growing globalization and by the emergence of the information society which some have defined as the post-truth society.

Few would doubt that European welfare states are challenged by such secular factors as aging, re-location of industries, robotization and the spread of nontraditional forms of employment, where people can no longer be automatically taxed for their contribution to social services. Additionally, few would doubt that the United States has entered a crossroad in making choices. In one alternative perspective, it would go more in the socially responsible state direction as advocated by Stiglitz (2019). By contrast, it could instead launch a second Thatcherite revolution, as the Trump Administration preaches. The new supply side revolution would include entering the road of financial de-regulation, tax 
cuts and economic protectionism cum foreign policy unilateralism. In both cases, the basics of the U.S. model as currently taught in comparative economic systems are to be modified in fundamental ways.

Finally the growth of the middle classes in Asia, from India via China to Iran, do pose challenges, political and economic, to the existing models of rule. The basic insight, elaborated with great erudition in the last book of the leading Polish economist, Jan Winiecki (2016) on the indispensable role of political and civic liberties in making the headway to a modern knowledge based economy, seems to hold stronger than ever.

Unless we completely misread the global situation, such challenges are going to confront all three major actors of the global economy. In Latin America and Africa, more traditional concerns of state-building and conventional economic consolidation may be on the agenda. Furthermore, in several failed states creating the minimum of civilized life is most likely yet to take decades to form-let us only refer to Somalia and Afghanistan where central government is next to nonexistent for over four decades by now. But most interestingly all three poles of global economic development do face deep ongoing challenges to their existing arrangements. Therefore peace, as we have been accustomed to it in the past seven decades, can by no means be taken for granted. It needs to be nurtured and changes in all other areas are, in turn, subjected to this supreme objective.

In order to ensure this fundamental condition for evolutionary and democratic change for the better, we can assume three major areas may and most likely will come to the forefront. Firstly, inside the territorial states participatory arrangements that allow identification with governmental objectives and social acceptance of even painful reforms has been seen as a precondition for good society to come about. The more we acknowledge the focal role of continuous institutional change in contemporary Asia (Huang and Yeung 2018), the less we may be content with propositions of simply replicating the successful South Korean developmental state model in North Korea. Moreover, the higher we see a chance for sustaining centralization in polity in North Korea, the even less so. Secondly, with the increasing role of finance in complex economic systems properly regulated, rather than unbridled, self-regulating finance is becoming a side condition for the social sustainability of a market society built on innovation (Shiller 2012). This is the exactly opposite to the line of the Trump Administration.

Lastly, cooperative solutions in the international arena, ruled by persuasion and agreement rather than imposing unilateral solutions, as disrupting the WTO framework, or de-emphasizing and diluting major new provisions for the Comprehensive and Progressive Agreement for Trans-Pacific Partnership signed 8 March, 2018, may deliver outcomes. Negotiation presumes strength, care, and attention to detail, comprehending the incomprehensible, such as the dictatorial regime in North Korea and its quest for survival. The self-defense mechanism of 
the regime may include denial for eventual de-nuclearization of any sort, for both propaganda and practical considerations. Patience and strategic thinking to bring about change, the historical vision last entertained by the Reagan Administration, may provide improvements under peaceful, evolutionary conditions on both the Korean peninsula and within global relations alike.

\section{References}

Acemoglu, Daron, and James A. Robinson. 2012. Why Nations Fail? The Origins of Power, Prosperity and Poverty. New York: Crown Publishers.

Berend, T. Iván. 2006. An Economic History of Twentieth Century Europe: from Laissez-faire to Globalization. Cambridge-New York: Cambridge University Press.

Blanchard, Olivier, Raguram Rajan, Kenneth Rogoff, and Lawrence Summers, eds. 2016. Progress and Confusion: the State of Macroeconomic Policy. Cambridge/Mass, New York: The MIT Press.

Bornstein, Morris. 1992. "Privatization in Eastern Europe." Communist Economies and Economic Transformation 4 (3): 283-320.

Braudel, Fernand. 1969. On History. Chicago, Illinois: University of Chicago Press.

Bruszt, László, and Gerard McDermott, eds. 2014. Leveling the Playing Field: Transnational Regulatory Integration and Development. New York: Oxford University Press.

Chun, Sung Hun. 2018. The Economic Development of South Korea. London: Routledge.

Costa-i-Font, Joao. 2014. "Furthering Sub-central Autonomy in Europe? The Roles of Identity and Re-Distribution." Intereconomics 49 (1): 36-45.

Csaba, László. 1993. "After the Shock. Some lessons from Transition Policies in Eastern Europe." In The Political Economy of the Transition Process in Eastern Europe, ed. L. Somogyi. Aldershot, UK and Brookfield, USA: Edward Elgar Publishing, 88-107.

Csaba, László. 2007. The New Political Economy of Emerging Europe, 2nd ed., rev. ed. Budapest: Akadémiai Kiadó.

de Vroey, Michel. 2016. A History of Macroeconomics from Keynes to Lucas and Beyond. New York: Cambridge University Press.

Du, Jun. 2018. The Political Economy of Contemporary China: An Institutional Analysis of Market and State. London: Routledge.

Haiduk, Kiryl. 2016. "Hayek and Coase Travel East: Privatization and the Experience of Post-Communist Economic Transformation.” In Hayek: A Collaborative Biography: Part VI, Good Dictators, Sovereign Producers and Hayek's 'Ruthless Consistency,' ed. Robert Leeson. London: Palgrave MacMillan, 249-80.

Huang, Flora, and Yeung, Horace, eds. 2018. Institutions and Economic Growth in Asia. London: Routledge.

Kaase, Max, Vera Sparschuch, and Agnieszka Weninger, eds. 2002. Handbook of Three Social Sciences in Central and Eastern Europe: Economics, Political Science and Sociology. Berlin - Budapest: GESIS Institut and Collegium Budapest.

Kim, Ba-Yoo. 2017. Unveiling the North Korean Economy: Collapse and Transition. New York: Cambridge University Press.

Kollmorgen, Rai, Wolfgang Merkel, and Hans-Jürgen Wagener, eds. 2019. Handbook of 
Political, Social and Economic Transformations. New York: Oxford University Press.

Kolodko, Grzegorz W., ed. 2014. Management and Economic Policy for Development. New York: Nova Science Publishers.

Kornai, János. 1993. “Transformational Recession: A General Phenomenon Examined through the Example of Hungary's Development.” Économie Appliquée 46 (2): 181227.

Kosals, Leonid. 2007. "Essay on Clan Capitalism in Russia." Acta Oeconomica 57 (1): 67-85.

Marangos, Jon. 2007. "Was 'Shock Therapy' Consistent with the Washington Consensus?" Comparative Economic Studies 49 (1): 32-58.

New York Times. "North Korea Tests Weapon." 17 April, 2019.

North, Douglass. 2005. Understanding the Process of Economic Change. Princeton, New Jersey: Princeton University Press.

Roaf, James, Ruben Atoyan, Bikas Joshi, and Krzysztof Krogulski. 2014. "25 Years of Transition: Post-Communist Europe and the IMF." IMF Regional Economic Issues, Special Report, October 14. Washington, DC: International Monetary Fund. http:// www.imf.org/external/pubs/ft/reo/2014/eur/eng/pdf/erei_sr_102414.pdf (accessed October 28, 2017).

Sen, Amartya. 1999. Development as Freedom. New York: Alfred Knopf.

Shiller, Robert J. 2012. Finance and the Good Society. Princeton, N.J: Princeton University Press.

Stiglitz, Joseph E. 2019. People, Power and Profits: Progressive Capitalism for the Age of Discontent. London: Allen Lane.

Szanyi, Miklós. 2016. "The Reversal of the Privatization Logic in the Central and Eastern European Transition Countries.” Acta Oeconomica 66 (1): 33-55.

Turley, Gerard, and Paul G. Hare, eds. 2013. Handbook on the Economics and Political Economy of Transition. London: Routledge.

Voszka, Éva. 2018. "Nationalizations in Hungary in the Post-crisis Years: A Specific Twist or a European Trend?" Europe-Asia Studies 70 (8): 1281-1301.

Wagener, Hans-Jürgen, ed. 1998. Economic Thought in Communist and Post-Communist Europe. London: Routledge.

Wang, Fei-Ling. 2018. "China and the Prospects of De-nuclearization of North Korea." Asian Journal of Peacebuilding 6 (2): 267-88.

Williams, Michelle, ed. 2014. The End of the Developmental State? London: Routledge.

Winiecki, Jan. 1993. "Knowledge of Soviet-type Economies and 'Heterodox' Stabilization in Eastern Europe." Weltwirtschaftliches Archiv 129 (2): 384-410.

Winiecki, Jan. 2002. "An Inquiry into the Early Drastic Fall of Output in Post-Communist Transition: An Unsolved Puzzle." Post-Communist Economies 14 (1): 5-29.

Winiecki, Jan. 2016. Shortcut or Piecemeal? Economic Development Strategies and Structural Change. Budapest- New York: CEU Press.

Winters, L. Alan, ed. 1995. Foundations of an Open Economy. London; Brussels: Center for Economic Policy Research and EU Commission.

World Bank. 2018. World Development Indicators Database, 2018. Washington, DC: World Bank.

Yakovlev, Andrei. 2006. "The Evolution of Business-State Interaction in Russia: From State Capture to Business Capture?” Europe-Asia Studies 58 (7): 1033-56. 
László Csaba is distinguished professor of international political economy, The Central European University and Corvinus University of Budapest, honorary professor of economics at Szent István University, Gödöllö, as well as member of the Hungarian Academy of Sciences. He is the author of 13 books, editor of 6 volumes, as well as 382 articles and chapters in books published in 22 countries. His recent publications include Válság, Gazdaság, Világ (English title: Crisis, Economy, Globalization) (Budapest: Éghajlat Kiadó, 2018) and "Liberalization: Waves and Counter-waves in Postcommunist Change" in Handbook of Political, Social and Economic Transformation (edited by Kollmorgen et al, Oxford University Press, 2019). More on his personal website: www.csabal.com. Email: csabal@ceu. edu.

Submitted: September 3, 2019; Revised: October 25, 2019; Accepted: October 29, 2019 
